

Journal home page: www.ijfsab.com

https://doi.org/10.30721/fsab2019.v2.i2

Research Article

\title{
Chemical composition of Sea-buckthorn and Highbush Blueberry fruits grown in the Republic of Belarus
}

\author{
Maria Zenkova $^{1 \boxminus}$, Julia Pinchykova $^{1 \boxminus}$ \\ ${ }^{1}$ Department of Food commodity research, Belarus State Economic University, Minsk, Belarus
}

\begin{abstract}
The object of the researches have been Sea-buckthorn (Hyppophae rhamnoides L.) of three varieties (Podarok sadu, Trofimovskaya, Botanicheskaya) and Highbush Blueberry (Vaccinium corymbosum L.) of five varieties (Duke, Bluetta, Bluecrop, Northland, Coville) grown in the Republic of Belarus. Sea-buckthorn and Highbush Blueberry fruits chemical composition has been studied during a three-year cycle of monitoring using standard methods and in accordance with technical legal acts of the Republic of Belarus. Solid content (13.0-15.3\%), sugar content (4,00$4,80 \%)$, organic acids (1.10-2.05\%), nitrogen substances content (0.29-0.46\%), lipids (3.6-6.2\%), pectin content

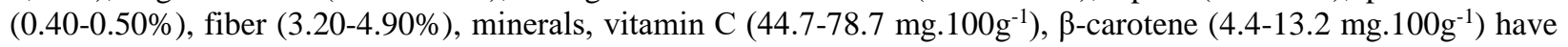
been studied in Sea-buckthorn (Hyppophae rhamnoides L.). Solid content (12.2-15.1\%), sugar content (2.73-3.96\%), organic acids (0.59-0.95\%), pectin content (0.57-0.97\%), fiber (1.20-1.68\%), bioflavonoids (276-368 mg. $\left.100 \mathrm{~g}^{-1}\right)$, bioflavonoids complex fractional composition (anthocyanins, leucoanthocyanins, catechines, flavonols), vitamin C (60.5-72.2 mg.100 g $\mathrm{g}^{-1}$ ) and mineral content have been studied in Highbush Blueberry (Vaccinium corymbosum L.). Exogenous contaminants content (arsenic, heavy metals), hygienical safety indexes, caesium 137 radionuclides content have been investigated in the fruits.
\end{abstract}

Keywords: sea-buckthorn, blueberry, amount of sugars, organic acids, fibers, vitamin, bioflavonoids, amino-acid composition, minerals, safety indexes.

\begin{abstract}
Abbreviations:
ODC - ornithine decarboxylase

DABC - dimetilaminoazobenzolsulfonilchlorid

${ }^{\square}$ Corresponding author: Associate professor Zenkova M., Candidate of Technical Sciences, the Department of Food commodity research, Belarus State Economic University, Minsk, Belarus. 26, Partizanski Av., Minsk, 220070, Republic of Belarus, phone: +375 17 2097929; E-mail: mariya_lz@mail.ru. Associate professor Pinchykova J., Candidate of Technical Sciences, the Department of Food commodity research, Belarus State Economic University, Minsk, Belarus, 26, Partizanski Av., Minsk, 220070, Republic of Belarus, phone: +375 17 2097929; E-mail: pinchykova@gmail.com
\end{abstract}

Article history:

Received 8 June 2018

Reviewed 11 August 2018

Accepted 16 November 2018

Available on-line 10 October 2019

https://doi.org/10.30721/fsab2019.v2.i2.59 (C) 2019 The Authors. UFT Academic publishing house, Plovdiv 


\section{Introduction}

State policy in the field of healthy diet provision to the population is implemented in the Republic of Belarus. The population is supposed to meet their needs in fresh and processed fruit including home produced berries. Food technologists are constantly carrying out researches on foodstuffs enrichment with bioactive substances and food fibers due to their well-known influence on man's health. Besides fresh fruit, berries and vegetables byproducts resulted from their processing are also the sources of such substances (Garcia-Amezqiuta et al. 2018). Sea-buckthorn (Hyppophae rhamnoides L.) and Highbush Blueberry (Vaccinium corymbosum L.) fruits are prospective baccate cultures in the Republic of Belarus possessing the unique set of useful substances.

Sea-buckthorn differs in large variety of forms depending on environmental conditions of its growth. As the result the scientists managed to select the high-yield Sea-buckthorn varieties having longer peduncles (which facilitates their berrying considerably) and high vitamins content with average berries mass of $0.8 \mathrm{~g}$ mainly oval form.

Highbush Blueberry is a bush up to $2.5 \mathrm{~m}$ height with large leaves and berries in bunch (from 4 to 12) having a diameter of $1.5-2.5 \mathrm{~cm}$. Pomological berries characteristics are various depending on varieties. The results of the successful introduction of the given plant in Belarus served as the preconditions for its wide-range introduction into the industrial culture. The program is implemented to increase its cultivation areas. The leading organizations in the Sea-buckthorn and Highbush Blueberry selection are RUE "Institute of Fruit growing" and Central Botanical Garden of the NAS of the Republic of Belarus (Turko et al. 2014). Scientists' works are devoted to the study of Seabuckthorn chemical composition (Yang et al. 2016; Yakovleva et al. 2011; Gulenkova 2013; Bal et al. 2011; Zadernowski et al. 2005; Ercisli et al. 2007).

It is known that the average chemical composition of sea-buckthorn berries is characterized by the following indicators $(\%)$ : water - 83.0; proteins 1.2; lipids 5.4; carbohydrates - 5.7; fiber - 2.0; organic acids - 2.0; ash - 0.7. Sea buckthorn contains minerals (mg per $100 \mathrm{~g}$ ): sodium - 4.0; potassium 193.0; calcium - 22.0; magnesium - 20.0; phosphorus - 9.0. and vitamins (mg per $100 \mathrm{~g}$ ): $\beta$ carotene - $14.0 ; \mathrm{B}_{1}-0.03 ; \mathrm{B}_{2}-0.05 ; \mathrm{PP}-0.40 ; \mathrm{C}$ 200 (Skurikhin and Tutel'yan 2002). Some works ground scientifically the high food value of Highbush Blueberry. It is known that the average chemical composition of Blueberry berries is characterized by the following indicators (\%):organic acids $-0.3-1.2 \mathrm{mg} .100^{-1} \mathrm{~g}$; bioflavonoid sum - 300-550 Mg; Highbush Blueberry contains minerals (mg per $100 \mathrm{~g}$ ): potassium - 312-470; calcium - 30-95; magnesium - 0.25-1.2; iron $0.66-1.2$; zink $-0.52-1.2$ and vitamins (mg per 100 g): C $-20-100 \mathrm{mg}$, vitamin A (0.1 $\mathrm{mg})$ and PP -0.8 mg (Shapiro et al. 1985, Rupasova et al. 2009, 2016, 2017).

In Belarus the selections of Sea-buckthorn and Highbush Blueberry adapted to weather conditions in the given area are studied. Cultivation areas and berries application in the various branches of industry are increased. It is due to the valuable chemical composition of studied berry varieties. The crucial issue in baccate varieties studying is a complex evaluation of berries chemical composition giving an idea about their bioactive substances content. At the same time it is generally known that useful substances accumulation characteristics depend on both variety distinctions and growing area. It determines the separate variety studying necessity. The purpose of the research is to study grown in the Republic of Belarus Seabuckthorn (Hyppophae rhamnoides L.) and Highbush Blueberry (Vaccinium corymbosum L.) chemical composition. The given purpose is implemented by the sequential decision of the following tasks: studying of Sea-buckthorn and Highbush Blueberry chemical composition and safety indexes.

\section{Materials and Methods}

The objects of the study were Sea-buckthorn berries grown in RUE "Institute of Fruit growing" experimental area, the village of Samokhvalovichy, Minsk Region: Botanicheskaya, Trofimovskaya, Podarok sadu; as well as Highbush Blueberry of five varieties introduced into the Republic of Belarus and grown in the fruit and berry introduction experimental area of Central Botanical Garden of the NAS of the Republic of Belarus, Gantsevichy 
District, Brest Region: Duke, Bluetta, Bluecrop, Northland, Coville. Sampling, preparation and testing were carried out by standard and special physical and chemical techniques. While studying the following methods were used: monitoring, comparison, calculation, measuring, experimenting, stating the similarity and generalization. The researches were conducted with the standard food product quality control methods and in accordance with techniques applying in Belarus: solids mass fraction with thermogravimetric analysis (GOST 28561 90), soluble solids mass fraction with refractometric analysis (GOST ISO 2173-2013), total sugars amount and reducing sugars mass fraction with permanganate method (GOST 8756.13-87), organic acids mass fraction with visual and potentiometric methods (GOST ISO 750-2013), vitamin $\mathrm{C}$ content with titrimetric method for the stained solutions (GOST 24556 89), fat mass fraction with gravimetric method (by Soxhlet), ash mass fraction with dry burning at temperature 400$600^{\circ} \mathrm{C}$ till all the organic substance are burned (GOST 25555.4-91). $\beta$-carotene content was defined with photometric determination of carotene mass concentration in the solution after carotene being extracted from the prepared berries with organic solvent and purified from concomitant staining agents by means of column chromatography. Pectin substances were determined with calcium-pectatic method for Seabuckthorn berries and with carbazolic method for the Highbush Blueberry ones. The calcium-pectate method is based on the precipitation of pectic acids in the form of calcium salts. The resulting calcium pectate precipitate is filtered through a paper filter that has been dried to constant weight and weighed with a weighing bottle. The filter cake is washed with $0.5 \% \mathrm{CaCl} 2$ solution and then 5-6 times with cold distilled water. The filter with sediment is transferred to a weighing bottle and dried to constant weight at temperature of $100-105^{\circ} \mathrm{C}$. The sediment mass is multiplied by 0.9235 in pectic acid terms. Fiber mass fraction was determined with the Kürschner and Ganek's method by Kogan's modification. The method is based on the purification of fiber from accompanying substances by treating the studied products with the mixture of strong acetic and nitric acids. At the same time the substances accompanying cellulose pass into the compounds soluble in acetic acid. The nitrogenous substances mass fraction was determined with protein analyzer Kjeltec 2200 . The method consists in the destruction of organic matter by heating with sulfuric acid in the presence of a catalyst adding sodium hydroxide in excess, distillation and titration of released ammonia. Mineral composition was determined with atomic-absorption spectrophotometer. The ash formed after the samples being calcinated was dissolved in concentrated hydrochloric acid by heating on an electric stove and evaporated. Distilled water was added and the dissolution was continued by heating. The resulting solution was filtered through a filter paper and transferred to a measuring flask with the capacity of $50 \mathrm{~cm}^{3}$. Metal ions in the resulting solutions were determined using air-acetylene flame for atomization. All metals were determined on the absorption behavior, sodium - on the emission behavior. Amino acid composition test was conducted by the method of high-efficiency liquid chromatography based on the protein acid hydrolysis, DABC - derived amino acids obtaining and their chromatography. The amino acids separation takes place in chromatographic column $250 \mathrm{~nm}$ long, in $4.6 \mathrm{~mm}$ diameter with the ODS phase $\left(\mathrm{C}_{18}\right)$. To measure amino acids concentration the spectrophotometric detector was used at $436 \mathrm{~nm}$ visible region. Quantitative data were calculated in the peak areas with the use of absolute calibration method. Polyphenol compound content and sum of tanning agents were determined by the Levental's volume method; based on the oxidation of all phenolic substances of investigated product with $\mathrm{KMnO} 4$ solution in the presence of the indigo carmine indicator. Sum of anthocyanin pigments by the Swain and Hillis' method; with the calibrating curve construction for crystalline cyanidine obtained from the chokeberry fruits; anthocyanins - by the Shnidman and Afanasjeva's method; sum of flavonols - by the Sarapuu and Meadle's method; sum of catechines - by the photometric method.The pesticides determination is based on the pesticides extraction with organic solvent from the product, the extract purification, its evaporation to dryness and thin-layer chromatography. The determination of patulin mycotoxin is based on the patulin extraction from the product with organic solvent, the extract 
purification and patulin determination using thinlayer chromatography. The patulin evaluation lower limit is $10 \cdot 10-7 \%$. The cesium 137 specific activity was measured with a scintillation gamma spectrometer in a pre-ground sample placed in a cuvette.

\section{Results and Discussion}

Sea-buckthorn and Highbush Blueberry fruit preparation included the inspection, ripeness separation, washing and mashing to obtain homogeneous mass. Mean data on Sea-buckthorn berries chemical composition are in Table 1 .

It is shown that the water content is $84.7-87.0 \%$ in all studied varieties. The soluble solids content depends on the variety (Trofimovskaya contains $8.80 \%$ soluble solids, Botanicheskaya $-6.80 \%$ ). Organic acids content varies within the range of $1.10 \%-2.05 \%$. Sea-buckthorn berries are low in sugars (4.0-4.8\%), including reducing ones - $34 \%$ in average from the total amount. Sugar and acid relation governing berries taste is 3.8 in Podarok sadu variety, 2.8 - Trofimovskaya, 1.9 Botanicheskaya. Thus, Botanicheskaya variety is sourer than Podarok sadu. But Sea-buckthorn berries are almost the only fruit with fat accumulated in seeds and pulp. The given varieties are characterized with average fat content $3.6 \%$ $6.2 \%$. Low nitrogenous substances content $(0.29 \%$ $-0.46 \%$ ) indicates that Sea-buckthorn berries are less important as protein supplier than meat, milk, legumes and cereals. However, nitrogenous substances govern organoleptic characteristics of Sea-buckthorn berries processing products (flavor, aroma, colour), keeping quality and vitamins preservation. It should be noted that Sea-buckthorn varieties are close in pectines $(0.4 \%-0.5 \%)$, but are different in fiber content (3.2\%-4.9\%). Fiber plays an important role in the regulation of body processes. Sea-buckthorn is a valuable source of carotenoids including $\beta$-carotene, its content being
The arithmetic mean values of the research results are given in the article. The experiments have been repeated 4-6 times in the harvested crop for 3 years. The safety indexes were determined according to techniques applying in Belarus.

one of the significant berry quality characteristic. Yellow Sea-buckthorn berries of the Botanicheskaya variety are the lowest in $\beta$-carotene content (4.4 mg. $100 \mathrm{~g}^{-1}$ ), Podarok sadu is the richest one (13.2 mg. $\left.100 \mathrm{~g}^{-1}\right)$. Chemical composition of Highbush Blueberry fruit was studied. The results are shown in Table 2. Solids content varies in the range of $12.2-15.1 \%$ during a three year period, Coville being the richest one. The range of organic acids accumulation is $0.59-0.95 \%$; total sugars 2.73-3.96\%, including reducing sugars $1.92-2.82 \%$, sucrose $-0.77-1.03 \%$. It is evidence of monosugars prevalence. In its turn it can be said that Highbush Blueberry fruit is a dietary product. Sugar and acid relation governing the berries taste varied from 3.5 to 6 depending on the variety, maximum being in Duke and Bluecrop. During the studied period pectin accumulation in the berries was $0.57-0.97$ $\%$, including hydropectin - 0.35-0.56\%, protopectin $-1.20-0.56 \%$. It should be noted that pectin and its fraction accumulation was dependable on the variety, maximum being in Coville. Studied baccate varieties are of practical interest as source of vitamin C. Vitamin C content in Highbush Blueberry and Sea-buckthorn berries during a three year period was defined. Mean results are shown in Figure 1. Vitamin C content in the studied Seabuckthorn varieties varied from 44.7 to 78.7 mg.100g-1 as opposed to Sea-buckthorn varieties grown in Altayskiy Kray, the Russian Federation (Yakovleva et al. 2011). But maximum variations depend on the climate conditions, Sea-buckthorn maturity and variety distinctions. 


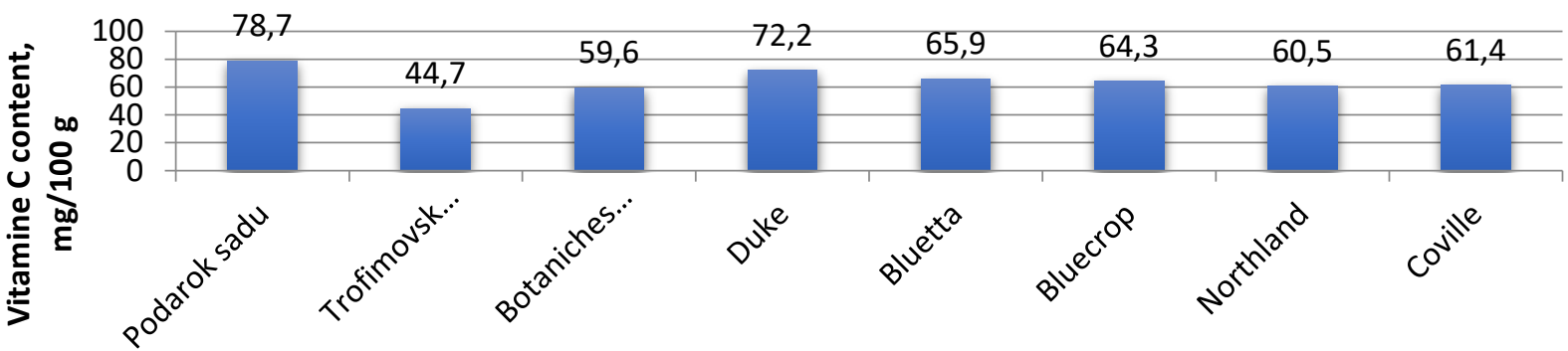

\section{Studied varieties}

Figure 1. Vitamin C content in Highbush Blueberry and Sea-buckthorn berries

The variation range of vitamin $\mathrm{C}$ content in Highbush Blueberry during a three year period is $60.5-72.2 \mathrm{mg} .100 \mathrm{~g}^{-1}$. In term of practice the estimation of possible use of Sea-buckthorn and Highbush Blueberry to correct of population's vitamin status is important. Vitamin $\mathrm{C}$ daily requirement for adults in the Republic of Belarus is
$90 \mathrm{mg}$. Thus, it is evident that $100 \mathrm{~g}$ of Seabuckthorn berries meet $87.5 \%$ (Podarok sadu), and Highbush Blueberry - 80.2 \% (Duke) of man's requirement in vitamin C. Sea-buckthorn aminoacids composition was studied for biological valuation of fresh berries (Table 3).

Table 1. Chemical composition of Sea-buckthorn berries

\begin{tabular}{|l|c|c|c|}
\hline \multirow{2}{*}{ Index } & \multicolumn{3}{|c|}{ Sea-buckthorn varieties } \\
\cline { 2 - 4 } & Podarok sadu & Trofimovskaya & Botanicheskaya \\
\hline Solids, \%, including & & & \\
soluble & $7.60 \pm 0.52$ & $8.80 \pm 0.34$ & $6.80 \pm 0.23$ \\
total & $14.40 \pm 0.60$ & $15.30 \pm 0.42$ & $13.00 \pm 0.40$ \\
\hline $\begin{array}{l}\text { Organic acids content } \\
\text { (in terms of malic acid), \% }\end{array}$ & $1.10 \pm 0.10$ & $1.71 \pm 0.12$ & \\
\hline Sugars content, \% & $4.20 \pm 0.20$ & $4.80 \pm 0.20$ & \\
- total & $1.41 \pm 0.02$ & $1.78 \pm 0.08$ & $4.00 \pm 0.22$ \\
- reducing & $3.60 \pm 0.10$ & $6.20 \pm 0.30$ & $1.29 \pm 0.08$ \\
\hline Fat content, \% & & & $4.10 \pm 0.10$ \\
\hline Nitrogenous substances content & $0.46 \pm 0.01$ & $0.29 \pm 0.06$ & \\
(total nitrogen), \% & $0.40 \pm 0.04$ & $0.50 \pm 0.02$ & $0.32 \pm 0.06$ \\
\hline Sum of pectines, \% & $4.70 \pm 0.05$ & $4.90 \pm 0.06$ & $0.40 \pm 0.01$ \\
\hline Fiber, \% & $13.20 \pm 0.40$ & $5.80 \pm 0.20$ & $3.20 \pm 0.03$ \\
\hline B-carotene content, mg/100g & & $4.40 \pm 0.10$ \\
\hline
\end{tabular}

Table 2. Chemical composition of Highbush Blueberry fruit

\begin{tabular}{|l|c|c|c|c|c|}
\hline \multirow{2}{*}{ Index } & \multicolumn{5}{c|}{ Highbush Blueberry varieties } \\
\cline { 2 - 6 } & Duke & Bluetta & Bluecrop & Northland & Coville \\
\hline Solids, \% & $13.3 \pm 0.6$ & $12.4 \pm 0.4$ & $13.3 \pm 3.4$ & $12.2 \pm 0.4$ & $15.1 \pm 0.4$ \\
\hline $\begin{array}{l}\text { Organic acids content } \\
\text { (in terms of citric acid), \% }\end{array}$ & $0.59 \pm 0.06$ & $0.71 \pm 0.08$ & $0.82 \pm 0.10$ & $0.59 \pm 0.08$ & $0.95 \pm 0.12$ \\
\hline $\begin{array}{l}\text { Sugars content, \% } \\
\text { - reducing }\end{array}$ & $3.60 \pm 0.25$ & $2.96 \pm 0.09$ & $3.96 \pm 0.14$ & $2.73 \pm 0.21$ & $3.34 \pm 0.11$ \\
\cline { 2 - 6 } sucrose & $2.48 \pm 0.01$ & $2.12 \pm 0.06$ & $2.82 \pm 0.06$ & $1.92 \pm 0.09$ & $2.24 \pm 0.09$ \\
\cline { 2 - 6 } $\begin{array}{l}\text { Sum of pectines \%, \%, } \\
\text { including } \\
\text { - hydrapectin } \\
\text { - protopectin }\end{array}$ & $0.98 \pm 0.05$ & $0.79 \pm 0.04$ & $0.91 \pm 0.06$ & $0.77 \pm 0.05$ & $1.03 \pm 0.01$ \\
\hline Fiber, \% & $0.67 \pm 0.04$ & $0.68 \pm 0.06$ & $0.68 \pm 0.06$ & $0.57 \pm 0.04$ & $0.97 \pm 0.08$ \\
\cline { 2 - 6 } & $0.25 \pm 0.01$ & $0.29 \pm 0.01$ & $0.28 \pm 0.01$ & $0.23 \pm 0,01$ & $0.41 \pm 0.01$ \\
\hline
\end{tabular}

Daily requirement for Belarussian adults 
The qualitative composition of Sea-buckthorn amino-acids varies slightly. 17 amino-acids were defined in Podarok sadu and Botanicheskaya varieties, 16 - in Trofimovskaya. Moreover, Trofimovskaya variety shows maximum aminoacids total amount. There are differences in aminoacids proportions depending on the variety. It is notable that seven essential amino-acids were defined in all the studied varieties. Their amount varies from $38.3 \%$ to $53.37 \%$ of the amino-acids total amount. Highbush Blueberry fruit has bright deep color from light-blue to deep-blue. It is evidence of high content of coloring agents possessing high biological value. Phenol compound total amount in Highbush blueberry fruit was defined in the course of the research. Single bioflavonoid fractions were studied (Table 4).

Table 3. Amino-acids composition of Sea-buckthorn, $\mathrm{mg} \cdot 100 \mathrm{~g}^{-1}$

\begin{tabular}{|l|c|c|c|}
\hline \multirow{2}{*}{ Amino-acids } & \multicolumn{2}{|c|}{ Sea-buckthorn varieties } \\
\cline { 2 - 4 } & Podarok sadu & Trofimovskaya & Botanicheskaya \\
\hline Asparaginic & $76.8 \pm 15.4$ & $58.0 \pm 11.6$ & $130.4 \pm 26.1$ \\
Glutamic & $11.5 \pm 22.3$ & $47.0 \pm 9.4$ & $78.2 \pm 15.6$ \\
Serine & $39.6 \pm 7.9$ & $27.3 \pm 5.5$ & $36.6 \pm 7.3$ \\
Threonine & $42.2 \pm 8.4$ & $39.0 \pm 7.8$ & $35.9 \pm 7.2$ \\
Glycine & $18.5 \pm 3.7$ & $33.5 \pm 6.7$ & $20.9 \pm 4.2$ \\
Alanine & $53.6 \pm 10.7$ & $67.8 \pm 13.6$ & $33.4 \pm 6.7$ \\
Arginine & $13.5 \pm 2.7$ & $15.6 \pm 3.1$ & $12.4 \pm 2.5$ \\
Proline & $38.5 \pm 7.7$ & $114.4 \pm 22.9$ & $40.3 \pm 8.1$ \\
Valine & $5.8 \pm 10.4$ & $197.4 \pm 39.5$ & $66.5 \pm 13.3$ \\
Methionine & $8.8 \pm 1.8$ & $115.3 \pm 23.1$ & $5.2 \pm 1.0$ \\
Leucine & $26.3 \pm 5.3$ & $55.5 \pm 1.1$ & $30.3 \pm 6.1$ \\
Isoleucine & $43.9 \pm 8.8$ & $100.5 \pm 20.1$ & $49.7 \pm 9.9$ \\
Phenylalanine & $30.4 \pm 6.1$ & $15.0 \pm 3.0$ & $25.1 \pm 5.0$ \\
Cysteine & $7.9 \pm 1.6$ & 0.0 & $11.6 \pm 2.3$ \\
Lysine & $34.5 \pm 6.9$ & $62.3 \pm 12.5$ & $57.5 \pm 11.5$ \\
Histidine & $11.7 \pm 2.3$ & $125.0 \pm 25.0$ & $25.4 \pm 5.1$ \\
Tyrosine & $10.8 \pm 2.2$ & $14.9 \pm 3.0$ & $28.3 \pm 5.7$ \\
\hline Total & $620.4 \pm 124.1$ & $1088.5 \pm 217.7$ & $687.7 \pm 137.5$ \\
quantity, & $237.9 \pm 47.4$ & $585.0 \pm 117.0$ & $270.2 \pm 54.0$ \\
including & & & \\
essential & & & \\
\hline
\end{tabular}

Table 4. Bioflavonoid and tanning agents content in Highbush Blueberry fruit, mg. $100 \mathrm{~g}^{-1}$

\begin{tabular}{|l|c|c|c|c|c|}
\hline \multirow{2}{*}{ Index } & \multicolumn{5}{c|}{ Highbush Blueberry variety } \\
\cline { 2 - 6 } & Duke & Bluetta & Bluecrop & Northland & Coville \\
\hline $\begin{array}{l}\text { Bioflavonoid sum, mg/100 } \\
\text { including }\end{array}$ & $340 \pm 23$ & $315 \pm 11$ & $358 \pm 23$ & $276 \pm 18$ & $368 \pm 21$ \\
\hline - anthocyanins & $1.46 \pm 0.87$ & $1.69 \pm 1.10$ & $0.45 \pm 0.10$ & $2.12 \pm 1.40$ & $1.72 \pm 0.90$ \\
\hline - leucoanthocyanins & $2.74 \pm 1.00$ & $2.23 \pm 0.85$ & $1.76 \pm 0.94$ & $2.65 \pm 1.00$ & $3.28 \pm 1.02$ \\
\hline - anthocyanins pigment sum & $4.20 \pm 0.42$ & $3.92 \pm 0.12$ & $2.21 \pm 0.10$ & $4.77 \pm 0.41$ & $4.98 \pm 0.65$ \\
\hline - catechins & $82 \pm 6$ & $80 \pm 8$ & $85 \pm 8$ & $61 \pm 4$ & $107 \pm 11$ \\
\hline - flavonols & $254 \pm 15$ & $231 \pm 20$ & $269 \pm 21$ & $209 \pm 14$ & $255 \pm 18$ \\
\hline Tanning agents, mg/100g & $0.29 \pm 0.09$ & $0.22 \pm 0.04$ & $0.31 \pm 0.12$ & $0.29 \pm 0.08$ & $0.38 \pm 0.10$ \\
\hline
\end{tabular}


Table 5. Content of mineral substances in Sea-buckthorn berries, mg.100 $\mathrm{g}^{-1}$

\begin{tabular}{|l|c|c|c|}
\hline \multirow{2}{*}{ Ash elements } & \multicolumn{3}{|c|}{ Sea-buckthorn varieties, $\mathbf{m}=\mathbf{3}$} \\
\cline { 2 - 4 } & Podarok sadu & Trofimovskaya & Botanicheskaya \\
\hline Ash content, \% & $0.360 \pm 0.018$ & $0.360 \pm 0.018$ & $0.380 \pm 0.019$ \\
Potassium & $22.000 \pm 9.80$ & $192.000 \pm 15.4$ & $117.000 \pm 9.4$ \\
Calcium & $7.100 \pm 0.57$ & $5.600 \pm 0.45$ & $6.000 \pm 0.48$ \\
Sodium & $19.600 \pm 1.57$ & $28.500 \pm 2.28$ & $19.900 \pm 1.59$ \\
Magnesium & $7.600 \pm 0.61$ & $6.600 \pm 0.53$ & $6.400 \pm 0.51$ \\
Iron & $0.440 \pm 0.0400$ & $0.310 \pm 0.0200$ & $0.540 \pm 0.0400$ \\
Manganese & $0.100 \pm 0.0100$ & $0.080 \pm 0.0100$ & $0.080 \pm 0.0100$ \\
Nickel & $0.023 \pm 0.0020$ & $0.016 \pm 0.0010$ & $0.015 \pm 0.0010$ \\
Copper & $0.085 \pm 0.0070$ & $0.057 \pm 0.0050$ & $0.049 \pm 0.0040$ \\
Zink & $0.120 \pm 0.0100$ & $0.120 \pm 0.0100$ & $0.120 \pm 0.0100$ \\
Cobalt & $0.015 \pm 0.0010$ & $0.008 \pm 0.0010$ & $0.008 \pm 0.0010$ \\
Chromium & $0.003 \pm 0.0002$ & $0.005 \pm 0.0004$ & $0.008 \pm 0.0010$ \\
\hline
\end{tabular}

Table 6. Content of mineral substances in Highbush Blueberry, mg. $100 \mathrm{~g}^{-1}$

\begin{tabular}{|c|c|c|c|c|c|}
\hline \multirow{2}{*}{$\begin{array}{c}\text { Ash } \\
\text { elements }\end{array}$} & \multicolumn{5}{|c|}{ Highbush Blueberry varieties, $\mathbf{m}=\mathbf{3}$} \\
\hline & Duke & Bluetta & Bluecrop & Northland & Coville \\
\hline $\begin{array}{l}\text { Ash } \\
\text { content, } \\
\%\end{array}$ & $0.189 \pm 0.004$ & $0.204 \pm 0.002$ & $0.178 \pm 0.001$ & $0.187 \pm 0.001$ & $0.288 \pm 0.004$ \\
\hline Calcium & $83.38 \pm 4.10$ & $97.76 \pm 5.22$ & $51.09 \pm 2.30$ & $36.06 \pm 1.50$ & $61.70 \pm 2.60$ \\
\hline Potassium & $337.0 \pm 7.13$ & $496.0 \pm 9.40$ & $361.0 \pm 8.74$ & $325.0 \pm 6.90$ & $350.0 \pm 5.26$ \\
\hline Copper & $0.042 \pm 0.008$ & $0.043 \pm 0.006$ & $0.066 \pm 0.010$ & $0.047 \pm 0.009$ & $0.054 \pm 0.008$ \\
\hline Iron & $0.812 \pm 0.09$ & $1.080 \pm 0.11$ & $0.825 \pm 0.065$ & $0.986 \pm 0.09$ & $0.768 \pm 0.012$ \\
\hline Zink & $0.366 \pm 0.023$ & $0.822 \pm 0.084$ & $0.450 \pm 0.012$ & $0.690 \pm 0.062$ & $0.795 \pm 0.042$ \\
\hline Manganese & $0.586 \pm 0.021$ & $0.351 \pm 0.010$ & $0.253 \pm 0.010$ & $1.083 \pm 0.091$ & $0.256 \pm 0.021$ \\
\hline Selenium & $0.037 \pm 0.006$ & $0.032 \pm 0.006$ & $0.040 \pm 0.011$ & $0.036 \pm 0.008$ & $0.038 \pm 0.005$ \\
\hline Iodine & $0.004 \pm 0.001$ & $0.004 \pm 0.001$ & $0.003 \pm 0.001$ & $0.003 \pm 0.001$ & $0.002 \pm 0.001$ \\
\hline
\end{tabular}

The data obtained describe Highbush Blueberry fruit as a source of bioflavonoids. Bioflavonoids content varies from 276 to $368 \mathrm{mg} .100 \mathrm{~g}^{-1}$ during the whole period of study, catechins and flavonols being prevail. Anthocyanin pigment content is 2.21 $4.98 \mathrm{mg} .100 \mathrm{~g}^{-1}$, catechins $-61.61-85.92 \mathrm{mg} .100 \mathrm{~g}^{-1}$, flavonols - 209-269 mg.100 $\mathrm{g}^{-1}$, tanning agents $0.22-0.38 \mathrm{mg} .100 \mathrm{~g}^{-1}$. Significant data changes in anthocyanins and catechins content in Highbush Blueberry fruit depending on the variety were defined. It should be taken into account when preventive purposed products with specified properties are developed. Mineral composition of Sea-buckthorn berries (Table 5) and Highbush Blueberry fruit (Table 6) was studied.

In the term of major mineral elements content Seabuckthorn berries are a valuable source of potassium, there being varieties differences in quantitative composition. Potassium content in Trofimovskaya is $40 \%$ as much as in Botanicheskaya. There is much less calcium, sodium and magnesium in Sea-buckthorn berries.
Variety distinctions vary from 15 to $30 \%$. Sodium content is low as well. In the term of trace elements Sea-buckthorn varieties differ insignificantly.

The analysis of the Highbush Blueberry varieties mineral composition study given in Table 6 shows the presence of wide variety of macro- and micronutrients in the berries. Mineral content quantitative composition varies depending on the variety $\left(\mathrm{mg} .100 \mathrm{~g}^{-1}\right)$ : $\mathrm{Ca} 36.06-97.76 ; \mathrm{K}$ 325-361; $\mathrm{Cu}$ 0.044-0.066, Fe 0.768-1.080; Zn 0.366-0.822; Mn 0.253-1.083; I 0.002-0.004; Se 0.032-0.040. Calcium, potassium, iron, zinc and iodine content maximum is in Bluetta. All the Highbush Blueberry varieties are rich in selenium (up to $90 \%$ of adults' daily requirement) which is an active antioxidant.

Deficiency or excess of any mineral elements in nutrition causes disorder of protein, fat, carbohydrates and vitamins metabolism. In its turn it results in a number of diseases. Man's body is not capable of building any mineral element. So it is necessary to take them in easy digestible form every day with natural food including berries. Seabuckthorn and Highbush Blueberry fruit grown in the Republic of Belarus was studied in the term of exogenous contaminant and Patulin mycotoxin content. Cs 137 specific activity was measured (Table 7). 
Table 7. Safety indexes of Sea-buckthorn and Highbush Blueberry fruit

\begin{tabular}{|c|c|c|c|}
\hline $\begin{array}{c}\text { Safety } \\
\text { indexes }\end{array}$ & $\begin{array}{l}\text { Acceptable } \\
\text { level in the } \\
\text { Republic of } \\
\text { Belarus, } \\
\text { no more }\end{array}$ & $\begin{array}{c}\text { Sea- } \\
\text { buckthorn }\end{array}$ & $\begin{array}{l}\text { Highbush } \\
\text { Blueberry } \\
\text { (Bluecrop) }\end{array}$ \\
\hline \multicolumn{4}{|c|}{ Exogenous contaminants, $\mathrm{mg} \cdot \mathrm{kg}^{-1}$} \\
\hline \multirow{2}{*}{$\begin{array}{l}\text { mercury } \\
\text { arsenium }\end{array}$} & 0.02 & $0.001 \pm 0.00$ & $0.0030 \pm 0.0008$ \\
\hline & 0.20 & $\begin{array}{c}01 \\
0,050 \pm 0.04\end{array}$ & $0.10 \pm 0.01$ \\
\hline \multirow{2}{*}{$\begin{array}{l}\text { lead } \\
\text { cadmium }\end{array}$} & 0.40 & $0.160 \pm 0,04$ & $0.090 \pm 0.004$ \\
\hline & 0.03 & $\begin{array}{c}0.030 \pm 0.00 \\
3 \\
\end{array}$ & $0.0010 \pm 0.0002$ \\
\hline \multicolumn{4}{|c|}{ Pesticides, mg.kg-1 } \\
\hline \multirow{2}{*}{$\begin{array}{l}\mathrm{HCH}(\alpha, \beta, \gamma) \\
\text { DDT and its } \\
\text { metabolites }\end{array}$} & 0.05 & not found & not found \\
\hline & & & \\
\hline $\begin{array}{l}\text { Patulin } \\
\text { mycotoxin, } \\
\text { mg.kg-1 }^{-1}\end{array}$ & 0.05 & not found & not found \\
\hline  & 70.0 & $<3.6$ & $9.4-12.6$ \\
\hline
\end{tabular}

\section{Conclusions}

Specific varieties characterictics of Sea-buckthorn (Hyppophae rhamnoides L.) and HighbusBlueberry (Vaccinium corymbosum L.) fruit chemical composition have been determined. The studied fruit is fully safe and can be recommended to be used both fresh and processed. The obtained results on chemical composition of Sea-buckthorn and Highbush Blueberry fruit grown in the Republic of Belarus prove that the given raw-material is a source of compounds performing important functions in the body. Sea-buckthorn berries are a source of

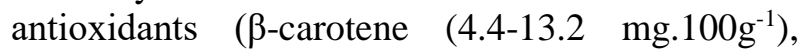
vitamin $\mathrm{C}$ (44.7-78.7 mg.100g $\left.\mathrm{g}^{-1}\right)$ ), dietary fibers (pectins $(0.4-0.5 \%)$, fiber $(3.2-4.9 \%)$ ), oil (3.6$6.2 \%)$, mineral elements. The differences among the studied Sea buckthorn varieties in terms of organic acids content (1.1-2.05\%), sugars (4.0-4.8\%), including reducing ones (1.29-1.78\%) and pectin substances were determined. The amino acid composition of Sea buckthorn berries was studied and 17 amino acids were found including 7 essential ones. Specific varieties characteristics of the amino acids qualitative and quantitative composition have been established. A wide range of Highbush Blueberry biologically active substances valuable for man's health was stated: bioflavonoids (276-368 mg. $\left.100 \mathrm{~g}^{-1}\right)$, catechins (61.61-85.92 mg.100g-1
It should be noted that toxic substances concentration in Sea-buckthorn and Highbush Blueberry fruit does not exceed acceptable levels prescribed by hygienic regulations in the Republic of Belarus. Patulin mycotoxin was not found. Cs 137 specific activity does not exceed threshold limit value. Moreover, analyzed indexes are substantially smaller than threshold limit values during the whole period of study. Thus, it can be said that Seabuckthorn and Highbush Blueberry fruit studied samples are fully safe for consumption and food production. It allows to use the given raw-materials both fresh and processed as food for the population.

vitamin C (60.5-72.2 mg.100g $\left.{ }^{-1}\right)$, selenium (0.032$\left.0.038 \mathrm{mg} .100 \mathrm{~g}^{-1}\right)$. There were no significant distinctions among studied Sea-buckthorn varieties in organic acids, sugars and pectin content. Amino acid composition of Sea-buckthorn berries was studied and 17 amino acids were found out including 7 essential amino acids. It was defined that amino acids quality and quantitative composition depend on a specific variety. As for Highbush Blueberry solids, titrating acid and sugars high variability was stated. It characterizes tastes diversity in the studied varieties (sugar and acid proportion 3.5-6). It was pointed out that pectin and its fractions accumulation depends on a variety distinction to a large degree, maximum being in Coville. The great amount of vitamin C (up to $80 \%$ of adults' daily requirement) was defined in Highbush Blueberry (Duke). The largest amount of calcium, potassium, iron, zinc and iodine was found in Bluetta. All the Highbush Blueberry varieties appeared to be rich in selenium (up to $90 \%$ of adults' daily requirement).

\section{Acknowledgements}

The study was carried out at the Mogilev State University of Food Technologies, Belarus. The authors appreciate the scientists of RUE "Institute of Fruit growing" and Central Botanical Garden of 
the NAS of the Republic of Belarus for their advice and support while selecting Highbush Blueberry and Sea-buckthorn varieties to be studied.

\section{References}

Bal L.M. Sea buckthorn berries: a potential source of valuable nutrients for nutraceuticals and cosmoceuticals. Food research international, 2011, 44(7): 1718-1727. http://www.sciencedirect.com/science/journal/09639969

Ercisli S., Orhan E., Ozdemir O., Sengul M. The genotypic effects on the chemical composition and antioxidant activity of sea buckthorn (hippophae rhamnoides 1.) berries grown in Turkey. Scientia Horticulturae, 2007, 115(1): 27 33.

https://doi.org/10.1016/j.scienta.2007.07.004

Gulenkova G.S. The biochemical composition peculiarities of the Sea-buckthorn berries. The Bulleten of KrasGAU, 2013, 11: 262-265. [in Russian] http://www.kgau.ru/vestnik

Garcia-Amezquita L.E., Tejada-Ortigoza V., Serna-Saldivar S.O., Welti-Chanes J. Dietary Fiber Concentrates from Fruit and Vegetable By-products: Processing, Modification, and Application as Functional Ingredients. Food and Bioprocess Technology, 2018, pp. 1-25, Print ISSN: 1935-5130, Online ISSN: 1935-5149. https://link.springer.com/journal/11947

Rupasova, Zh. Variability of structure of biochemical composition of fruits of the highbush blueberry / Rupasova Zh., Pavlovskij N., Kurlovich T., Pyatnitsa F., Yakovlev A., Volotovich A., Pinchukova Yu. // Agronomijas vestis. Latvian Journal of Agronomy. 2009. №12: 103-107. http://llufb.llu.lv/conference/agrvestis/content/n12/LatviaAgronomijas-Vestis-12-2009.pdf

Rupasova Zh., Reshetnikov V., Vasilevskaya T., Pavlovsky N. Transformation of the biochemical composition of Vaccinium Corymbosum fruit during storage. European Chemical Bulletin, 2016, 5(3), 77-81 http://www.eurchembull.com/index.php/ECB/article/view/ $1748 / 240$

Rupasova Zh, Yakovlev A., Pavlovsky N., Titok V., Reshetnikov V., et al. Genotypic distinctions of variability of biochemical composition of fruits of Vacciniaceae species under conditions of Belarus. Eur. Chem. Bull., 2017, 6(1), 5-12

Skurikhin I.M., Tutel'yan V.A., Khimicheskiy sostav rossiyskikh pishchevykh produktov: spravochnik. Moskva: DeLi print, 2002, pp. 156-157

Turko S.A., Samus V.A., Kozlovskaya Z.A. History of scientific fruit growing in Belarus. Izvestiya of the National Academy of Sciences of Belarus. Series of Agricultural Sciences, 2014, 3:3-15. http://vesti.belal.by

Vereshkovski, V.V. and Shapiro, D.K., Anthocyanin glycosides in the fruit of highbush blueberry cultivars, Khim. Prir. Soedin., 4, 570, 1985

Yakovleva T.P., Filimonova E.Y. Food and biological value of fruits of Sea-buckthorn berries. Food processing industry, 2011, 2:11-13.[in Russian]. http://www.foodprom.ru

Yang W. Proanthocyanidins in Sea Buckthorn (Hippophaë rhamnoides L.) Berries of Different Origins with Special Reference to the Influence of Genetic Background and Growth Location. Journal of Agricultural and Food Chemistry, 2016, 64(6). https://www.researchgate.net/publication/291517534

Zadernowski R., Naczk M., Czaplicki S., Rubinskiene M., Szalkiewicz M. Composition of phenolic acids in sea buckthorn (Hippophae rhamnoides L.) berries. JAOCS, Journal of the American Oil Chemists' Society, 2005, 82(3), pp. 175-179.

https://elibrary.ru/title_about.asp?id=18128 